\title{
EFFECT OF CRUDE GLYCEROL AS A SUBSTITUTE FOR CORN WITH OR WITHOUT FIBROLYTIC ENZYMES ON PRODUCTIVE PERFORMANCE OF LACTATING BALADI GOATS
}

\author{
Wafaa M.A. Ghoneem ${ }^{1}$; Mervat S.H. Youssef ${ }^{2}$; and M.R. Rashid ${ }^{2}$ \\ ${ }^{1}$ Animal Production Department, Faculty of Agriculture, Cairo University, Giza, Egypt. \\ ${ }^{2}$ Regional Center for Food and Feed, Agricultural Research Center, Giza, Egypt.
}

(Received 14/9/2015, accepted 25/10/2015)

\section{SUMMARY}

$\mathrm{T}$ This study was carried to investigate the effect of corn substitution by $50 \%$ crude glycerol with or without fibrolytic enzymes in lactating Baladi goats ration on digestibility, nutritive values, rumen liquor and blood parameters and lactation performance. Thirty multiparous lactating Baladi goats after 7 days of parturition were divided into three groups (10 animals each) according to its production then, the experimental groups were randomly assigned to fed one of the following experimental rations, control ration (R1) consists of $60 \%$ concentrate feed mixture and $40 \%$ Egyptian clover, R2, 50\% of corn was substituted with crude glycerol or R3, consists of R2 supplemented with fibrolytic enzymes (ALLZYMETM) at level of $6 \mathrm{~g} / \mathrm{kg}$ DM. Although, inclusion of glycerol alone (R2) or with fibrolytic enzymes (R3) in lactating goat rations decreased nutrients and fiber fractions digestibility and nutritive value as TDN, but they did not significantly $(\mathrm{P}<0.05)$ differ with control $(\mathrm{R} 1)$ in $\mathrm{DCP}$, blood and rumen liquor parameters, milk yield and composition. Addition of fibrolytic enzymes to glycerol ration (R3) increased nutrients digestibility, nutritive values and milk fat content compared with ration containing glycerol alone (R2). It could be concluded that crude glycerol could be used as a source of energy in ruminant rations with fibrolytic enzymes as additive without negative effects on lactating goats' health and performance.

Keywords: Crude glycerol, fibrolytic enzymes, lactating Baladi goats and productive performance.

\section{INTRODUCTION}

The expansion of the biofuels production around the world has provided opportunities for alternative energy sources for livestock feeding. This industry expansion is expected to increase availability and promote favorable pricing of glycerol (Thompson and He, 2006). It is estimated that by 2016 the world biodiesel market will achieve the quantity of 37 billion gallons, which means that more than 4 billion gallons of crude glycerol will be produced every year (Kośmider et al., 2011).

Glycerol, the main component of glycerine, is a glucogenic substrate for ruminants that can be converted to glucose in the liver and provide energy for cell metabolism (Goff and Horst, 2001). Therefore, glycerol may be a good source of energy for lactating animals. The energy value of glycerol was estimated by several studies which found to be similar to that of corn grains (Schröder and Südekum, 1999 and Mach et al., 2009). According to the FDA (2006), glycerol is recognized as a safe ingredient for use in animal feeds. It contains 80-90\% glycerol and water with small amounts of ash (mainly $\mathrm{NaCl}$ ), free fatty acids and traces of methanol and protein (Kerr et al., 2009).

Donkin et al. (2009) indicated that glycerol can replace corn grain as much as $15 \%$ in rations for dairy animals. Abo El-Nor et al. (2010) observed that corn substitution with glycerol at low level (36 g/kg DM) had no adverse effect on digestibility of DM, NDF and ADF compared with control. Also, Wilbert et al. (2013) stated that addition of glycerol up to $120 \mathrm{~g} / \mathrm{kg}$ of total DM intake in partial replacement of ground corn grain had no negative effect on productive performance of dairy cows or nutrients digestibility. Rumen propionate and butyrate concentrations (expressed as percentages of total VFA) were significantly greater $(\mathrm{P}<0.05)$ for cows fed glycerol, at the expense of acetate and isobutyrate (Boyd et al., 2013 and Carvalho et al., 2011), which caused a decrease in milk fat content. Different additives such as fibrolytic enzymes were suggested to alleviate the negative effect of glycerol on milk fat content by their effects on rumen $\mathrm{pH}$ stabilization or digestion improvement (Arriola et al., 2011 and Kung et al., 
2000). Hanafy et al. (2015) observed that substitution of 25 or $50 \%$ yellow corn by crude glycerol had the potential to improve in vitro DM and OM disappearance and gas production especially when combined with fibrolytic enzyme (ALLZYMETM). In lactating goats, Khattab et al. (2012) stated that feeding lactating goats on ration contained glycerol plus $4 \mathrm{~g} / \mathrm{kg}$ DM fibrolytic enzyme improved nutrients digestibility of DM, OM, CP, NDF, ADF and milk production compared with feeding glycerol ration without additives.

The objective of this study was to investigate the impact of corn substitution with crude glycerol by $50 \%$ with or without fibrolytic enzyme on lactation performance, digestibility and rumen and blood parameters of lactating baladi goats.

\section{MATERIALS AND METHODS}

\section{Experimental animals and rations:}

Thirty multiparous lactating Baladi goats, 5 years old and an average weight $33 \mathrm{~kg}$, after 7 days of parturition were divided into three groups (10 animals each) according to its production then, the experimental groups were randomly assigned to fed one of the following experimental rations control ration (R1) consists of $60 \%$ concentrate feed mixture and $40 \%$ Egyptian clover (Trifolium alexandrinum) according to nutrients requirement recommendation of NRC (1981), R2, 50\% of corn was substituted with crude glycerolor R3, consists of R2 supplemented with fibrolytic enzymes (ALLZYME ${ }^{\mathrm{TM}}$ ) at level of $6 \mathrm{~g} / \mathrm{kg}$ DM. The experiment consisted of two experimental periods (21 days adaptation period and 9 days collection period).

The experimental rations used in this study were formulated to be iso-caloric and iso-nitrogenous (Table 1).

Table (1). Formulation of the experimental rations.

\begin{tabular}{lcc}
\hline \multirow{2}{*}{ Ingredients \% } & \multicolumn{2}{c}{ Experimental rations } \\
\cline { 2 - 3 } & $\mathrm{R} 1$ & $\mathrm{R} 2, \mathrm{R} 3$ \\
\hline Yellow corn & 25 & 12.5 \\
Soybean meal & 5 & 5 \\
Cottonseed meal & 7.5 & 7.5 \\
Wheat bran & 20 & 20 \\
Crude glycerol & 0 & 12.5 \\
Clover hay & 40 & 40 \\
Urea & 0 & 0.5 \\
Minerals and vitamins & 2.5 & 2 \\
\hline Rl: control ration (without glycerol). R2: replacing $50 \%$ of corn with crude glycerol. $R 3:$ R2 +6 g/kg DM fibrolytic \\
enzymes (ALLZYME SSF containing per gram: 300 standard phytase units, 700 protease unit, 40 carboxymethyl \\
cellulase units, 100 xylanase units, 200 beta glucanase units, 30 fungal amylase units, 4000 pectinase units).
\end{tabular}

\section{Feeding procedures:}

The concentrate feed mixtures and Egyptian clover were divided into two equal portions fed twice daily at 0800 and $1600 \mathrm{~h}$. Fresh water was available at all times.

\section{Milk sampling:}

Goats were milked twice daily by hand milking at 0700 and $1900 \mathrm{hr}$. Milk yields were recorded during five successive days from the collection period. Milk samples were collected three times during the collection period (at first, third and fifth day). Whereas, one tenth of the morning and the evening milk yields were mixed for each animal and stored at $\left(-18^{\circ} \mathrm{C}\right)$ for further analysis.

\section{Digestion trial:}

After milk collection period, digestion trial was carried out using all animals for three successive days via acid insoluble ash (AIA) method according to Gallups et al. (1945) and Forbes and Garrigus (1948). Nutrients digestibility were calculated according to the following formula: 


$$
\text { Digestion coefficient }=100-\left[100 \times \frac{\text { gh idicator in fegd }}{\text { 96 indicator in feces }} \times \frac{96 \text { nutrient in feces }}{96 \text { nutrient in feed }}\right]
$$

\section{Feces sampling:}

Feces samples were taken during the collecting periods from each animal using fecal grab method. Subsample $(10 \%)$ of total collected feces was sprayed with $10 \%$ sulfuric acid, and then dried at $70^{\circ} \mathrm{C}$ for 24 hour. Dried feces were ground and kept individually for chemical analysis.

\section{Rumen liquor sampling:}

At the end of feces collection period, rumen liquor samples were collected by stomach tube from each animal at zero, 2, 4 and $6 \mathrm{hrs}$ post-feeding. Samples were strained through two layers of cheese cloth and immediately used for determination of ruminal liquor $\mathrm{pH}$ using digital $\mathrm{pH}$-meter. Rumen fluid samples were stored in glass bottles after adding ortho-phosphoric acid and stored at deep freeze $\left(-18^{\circ} \mathrm{C}\right)$ for analysis of ammonia nitrogen (NH3-N), total volatile fatty acids (TVFA's).

\section{Blood sampling:}

Blood samples were taken from jugular vein from each animal at the last day of experimental period after 4 hrs. of the morning feeding in tubes contains Ethylene Diamine Tetra Acetic acid (EDTA) as anticoagulant. Blood plasma was obtained by centrifugation at $4000 \mathrm{rpm}$ for 20 minutes and kept at deep freeze $\left(-18^{\circ} \mathrm{C}\right)$ for further analysis.

\section{Analytical procedures:}

\section{Feeds and feces analysis:}

Chemical analysis of feedstuffs and feces samples were carried out according to AOAC (2012). The nitrogen free extract (NFE) was calculated by difference. Fiber fractions were determined in feeds and feces according to Goering and Van Soest (1970).

\section{Rumen liquor analysis:}

Values of rumen $\mathrm{pH}$ were determined using Hanna digital $\mathrm{pH}$ meter. The concentration of ammonianitrogen $\left(\mathrm{NH}_{3}-\mathrm{N}\right)$ in the rumen liquor was determined by Kjeldahl distillation method (AOAC, 1995). Rumen total volatile fatty acids were determined by steam distillation method as described by Warner (1964) using Mrkham micro distillation apparatus.

\section{Blood plasma analysis:}

Blood plasma total protein and creatinine were measured as described by Tietz (1986 and 1990). Blood plasma albumin was determined according to Doumas et al. (1971). Blood plasma urea was determined according to Patton and Grouch (1977). Alanin amino transferase (ALT) and of aspartate amino transfearse (AST) were determined by the methods of Young (1990).

\section{Milk analysis:}

Milk samples were analyzed for total solids, fat, true protein and lactose by infrared spectrophotometer (Foss matic 120 Milko-Scan, Foss Q3 183 Electric, Hillerød, Denmark) according to AOAC (1995). Solids not fat content of milk was calculated by the difference between total solids and fat content.

\section{Statistical analysis:}

Data were analyzed by the least squares procedure of the General Linear Models Program of SAS (2009) according to procedures outlined by Snedecor and Cochran (1982).

Data of milk yield, milk composition, nutrients digestibility's and blood plasma parameters were analyzed using one way analysis of variance. The model used was as following:

$$
y_{i j}=\mu+T_{i}+e_{i j}
$$

Where:

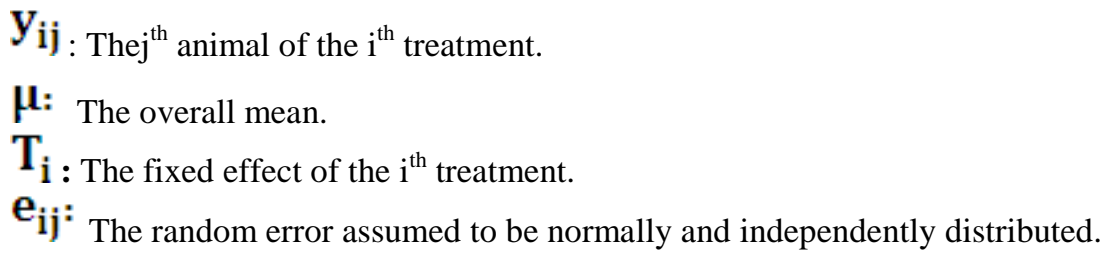


Model for repeated measures was used for rumen liquid parameters analysis. The model was as following:

Where

$$
\mathbf{y}_{\mathrm{ijk}}=\mu+\mathbf{T}_{\mathrm{i}}+\mathbf{B}_{\mathrm{j}}+(\mathbf{T B})_{\mathrm{ij}}+\mathbf{e}_{\mathrm{ijk}}
$$

$\mathbf{y}_{\mathrm{ij}} \mathrm{k}$ : The $\mathrm{k}^{\text {th }}$ animal of the $\mathrm{i}^{\text {th }}$ treatment within the $\mathrm{j}^{\text {th }}$ sampling time.

$\boldsymbol{\mu}:$ The overall mean.

$\mathbf{T}_{\mathbf{i}}$ : The fixed effect of the $\mathrm{i}^{\text {th }}$ treatment.

$\mathbf{B}_{\mathbf{j}}$ : The fixed effect of the $\mathrm{j}^{\text {th }}$ sampling time.

(TB) $)_{\mathrm{ij}}$ : The interaction between the $\mathrm{i}^{\text {th }}$ treatment and the $\mathrm{j}^{\text {th }}$ sampling time.

$\mathbf{e}_{\mathrm{ij}} \mathbf{k}$ : The random error assumed to be normally and independently distributed.

The Duncan's New Multiple range test (Duncan, 1955) and Least Square Means, LSM (Steel and Torrie, 1980) procedures were used to test the significance among means for data of milk yield, milk composition, nutrients digestibility's, rumen parameters and blood plasma parameters. Significance level was set at $\mathrm{p}<0.05$.

\section{RESULTS AND DISCUSSION}

\section{Chemical composition and fiber fractions of concentrate feed mixtures, clover and total mixed rations:}

The data of chemical composition (Table 2) showed that concentrate feed mixture containing glycerol (CFM2) had lower DM content compared with control concentrate feed mixture (CFM1).

Table (2). Chemical composition of clover, concentrate feed mixtures and experimental rations (DM basis).

\begin{tabular}{lccccc}
\hline \multirow{2}{*}{ Item } & \multicolumn{3}{c}{ Feedstuffs } & \multicolumn{2}{c}{ Experimental rations } \\
\cline { 2 - 6 } & Clover & CFM1 & CFM2 & R1 & R2\&R3 \\
\hline DM & 91.20 & 92.70 & 82.40 & 92.09 & 86.21 \\
Chemical composition, \% (DM basis): & & & & \\
OM & 89.76 & 87.81 & 87.60 & 88.60 & 88.53 \\
CP & 15.57 & 12.73 & 13.35 & 13.88 & 14.31 \\
CF & 27.48 & 5.23 & 5.63 & 14.23 & 15.09 \\
EE & 2.30 & 3.95 & 4.22 & 3.28 & 3.39 \\
NFE & 44.41 & 65.90 & 64.40 & 57.21 & 55.74 \\
Ash & 10.24 & 12.19 & 12.40 & 11.40 & 11.47 \\
Fiber fractions, \%: & & & & \\
NDF & 42.76 & 22.57 & 21.71 & 30.74 & 30.83 \\
ADF & 37.87 & 12.36 & 13.42 & 22.68 & 24.01 \\
ADL & 7.25 & 4.12 & 4.68 & 5.39 & 5.79 \\
Hemicelluloses & 4.89 & 10.21 & 8.29 & 8.06 & 6.82 \\
Cellulose & 30.62 & 8.24 & 8.74 & 17.29 & 18.22 \\
Lignin & 6.56 & 2.68 & 2.50 & 4.25 & 4.26
\end{tabular}

CFM1: control concentrate feed mixture (without glycerol), CFM2: replacing 50\% of corn with crude glycerol, R1:CFM1 + clover, R2:CFM2 + clover, R3: CFM2 + clover + fibrolytic enzymes.

Also, rations contained glycerol (R2 and R3) had the same trend. This reduction in DM content was expected as a result of corn replacement (solid form) by crude glycerol (liquid form).

The contents of OM, CF, EE, NFE and ash were similar for CFM1 and CFM2. While, CP was little bit higher in CFM2 than in CFM1. This could be attributed to urea addition in CFM2 to formulate isonitrogenous rations. Fiber fractions contents either of control or 50\% glycerol CFM were almost equal in ADL, cellulose and lignin. Otherwise, the NDF and hemicellulose fractions were less in CFM2 as a result of non-fiber material (glycerol) included in ration. On the same trend, all nutrients and fiber fractions 
contents were similar in all experimental rations. While, Khattab et al. (2012) found that dietary NDF, $\mathrm{ADF}$ and ether extract contents decreased with glycerol containing rations.

\section{Nutrients digestibility and nutritive values:}

Effect of different experimental rations fed to lactating Baladi goats on digestion coefficients and nutritive values are presented in Table (3). Data indicated that replacing 50\% of corn with crude glycerol (R2) significantly $(\mathrm{P}<0.05)$ decreased the digestibility of DM, OM, CP, CF, NFE, NDF, ADF, hemicelluloses and cellulose compared with the control ration (R1). Ether extract did not significantly $(\mathrm{P}<0.05)$ differ among the tested ration. The strong negative effect of high glycerol levels included in rations on cellulolytic microbial activity, and consequently, fiber digestion may explain the previous results (Abu Ghazaleh et al., 2011).

In the same trend, Abo El-Nor et al. (2010) found that feeding glycerol at 72 or $108 \mathrm{~g} / \mathrm{kg} \mathrm{DM}$ reduced digestibility of NDF and ADF compared with control. Also, Khattab et al. (2012) recorded significant $(\mathrm{P}<0.05)$ decreases in digestibility of DM, OM, NDF and ADF when replaced $30 \%$ of yellow corn by glycerol in lactating baladi goats ration. On the other hand, Donkin et al. (2009), Wang et al. (2009) and Boyd et al. (2011) observed an increase in DM digestibility when glycerol was included in rations. However, Wilbert et al. (2013) and Chanjula et al. (2014) observed that digestibility of DM, OM and NDF were not affected $(\mathrm{P}>0.05)$ by inclusion of glycerol either in the rations of dairy cows or goats, respectively.

Table (3). Effect of experimental rations fed to lactating goats on digestion coefficients.

\begin{tabular}{lcccc}
\hline \multirow{2}{*}{ Item } & \multicolumn{3}{c}{ Experimental rations } \\
\cline { 2 - 4 } & $\mathrm{R} 1$ & $\mathrm{R} 2$ & $\mathrm{R} 3$ & $\underline{\mathbf{}}$ \\
\hline Nutrient digestibility (\%): & & & \\
DM & $77.62^{\mathrm{a}}$ & $70.62^{\mathrm{c}}$ & $72.99^{\mathrm{b}}$ & 1.07 \\
OM & $80.39^{\mathrm{a}}$ & $73.34^{\mathrm{c}}$ & $75.60^{\mathrm{b}}$ & 1.05 \\
CP & $79.33^{\mathrm{a}}$ & $73.81^{\mathrm{b}}$ & $76.36^{\mathrm{ab}}$ & 0.98 \\
CF & $52.62^{\mathrm{a}}$ & $41.02^{\mathrm{c}}$ & $48.64^{\mathrm{b}}$ & 1.72 \\
EE & 72.67 & 69.93 & 70.00 & 0.62 \\
NFE & $88.00^{\mathrm{a}}$ & $82.17^{\mathrm{b}}$ & $83.04^{\mathrm{b}}$ & 0.97 \\
NDF & $63.93^{\mathrm{a}}$ & $47.97^{\mathrm{c}}$ & $52.16^{\mathrm{b}}$ & 2.43 \\
ADF & $64.74^{\mathrm{a}}$ & $46.67^{\mathrm{c}}$ & $55.40^{\mathrm{b}}$ & 2.64 \\
Hemicellulose & $61.65^{\mathrm{a}}$ & $52.58^{\mathrm{b}}$ & $40.76^{\mathrm{c}}$ & 3.08 \\
Cellulose & $73.78^{\mathrm{a}}$ & $60.10^{\mathrm{c}}$ & $66.52^{\mathrm{b}}$ & 2.05 \\
Nutritive value (\%): & & & \\
TDN & $74.21^{\mathrm{a}}$ & $67.89 \mathrm{c}$ & $69.89^{\mathrm{b}}$ & 1.01 \\
DCP & 11.01 & 10.56 & 10.93 & 0.11 \\
\hline a,b, c..... Means in the same row with different superscript are significantly different $(P<0.05)$.
\end{tabular}

Adding fibrolytic enzymes in $\mathrm{R} 3$ significantly $(\mathrm{P}<0.05)$ enhance nutrients and fiber fractions digestibility compared with R2. Khattab et al. (2012) found that combination of fibrolytic enzymes with glycerol ration significantly $(\mathrm{P}<0.05)$ improved the digestibility of all nutrients compared either with control or glycerol without additives. Boyd et al. (2011) explained the improvement in DM and ADF digestibility when direct-fed microbial was added to dairy cows ration contained glycerol by the improvement in ruminal fermentation.

The positive effect of fibrolytic enzymes might be explained by creating a stable enzyme-feed complex that protects free enzymes from proteolysis in the rumen (Kung et al., 2000). Several potential modes of action have been proposed, included: 1) increasing the microbial colonization of feed particles (Yang et al., 1999), 2) enhancing attachment and /or improve access to the cell wall matrix by ruminal microorganisms which result in accelerating the rate of digestion (Nsereko et al., 2000), 3) enhancing the hydrolytic capacity of the rumen due to added enzyme activities and/or synergy with rumen microbial enzymes (Newbold, 1997 and Morgavi et al., 2000) and 4) enzymes were able to degrade complex substrate to simpler ones, allowing a faster ruminal microbial colonization and fermentation (Colombatto et al., 2003). 
There was a significant $(\mathrm{P}<0.05)$ difference among the experimental rations in the nutritive value as TDN where the control recorded the best TDN value followed by R3 then R2. No significant difference was observed in DCP among the experimental rations.

\section{Rumen liquor parameters:}

Data concerning rumen liquor parameters (Table 4) showed that goats fed R3 had the highest mean value of ruminal $\mathrm{pH}$ compared to those fed R2 and R1. While, Khattab et al. (2012) and Chanjula et al. (2014) recorded no significant difference between lactating goats fed glycerol or control ration in ruminal $\mathrm{pH}$ value. Ruminal $\mathrm{pH}$ values, especially for animal fed $\mathrm{R} 3$ were above 6.5 that indicated a better digestion of cellulolytic materials (Mertens, 1978). These results may be due to the intensive fermentation process of both nonstructural and structural carbohydrates and the production of volatile fatty acids. Such results are supported by the finding of Azzaz (2009) and Farahat (2014) who observed that fibrolytic enzymes treatment significant increased ruminal $\mathrm{pH}$.

Table (4). Effect of experimental rations on rumen liquor parameters of lactating goats.

\begin{tabular}{lccccc}
\hline \multirow{2}{*}{ Item } & Sampling & \multicolumn{3}{c}{ Experimental rations } & \multirow{2}{*}{ \pm SE } \\
\cline { 3 - 5 } & Time & $\mathrm{R} 1$ & $\mathrm{R} 2$ & $\mathrm{R} 3$ & \\
\cline { 3 - 5 } Rumen pH & 0 & 7.06 & 7.00 & 7.05 & 0.11 \\
& 2 & $6.11^{\mathrm{b}}$ & $6.23^{\mathrm{b}}$ & $6.60^{\mathrm{a}}$ & 0.26 \\
& 4 & $6.40^{\mathrm{b}}$ & $6.72^{\mathrm{a}}$ & $6.81^{\mathrm{a}}$ & 0.22 \\
& 6 & $6.77^{\mathrm{b}}$ & $7.02^{\mathrm{a}}$ & $7.14^{\mathrm{a}}$ & 0.18 \\
& Mean & $6.59^{\mathrm{b}}$ & $6.74^{\mathrm{ab}}$ & $6.90^{\mathrm{a}}$ & 0.01 \\
\hline TVFA's (meq/dl rumen liquor) & 0 & 2.60 & 3.73 & 3.60 & 0.32 \\
& 2 & 6.07 & 6.13 & 6.60 & 0.18 \\
& 4 & 4.27 & 5.53 & 5.87 & 0.55 \\
& 6 & 3.67 & 3.27 & 2.60 & 0.33 \\
& Mean & 4.15 & 4.67 & 4.67 & 0.28 \\
\hline $\mathrm{NH}_{3}$-N (mg/dl rumen liquor) & 0 & $6.53^{\mathrm{b}}$ & $5.38^{\mathrm{b}}$ & $9.64^{\mathrm{a}}$ & 0.68 \\
& 2 & 20.83 & 16.81 & 18.32 & 0.93 \\
& 4 & $8.55^{\mathrm{b}}$ & $9.38^{\mathrm{b}}$ & $15.76^{\mathrm{a}}$ & 1.39 \\
& 6 & 4.67 & 4.46 & 4.96 & 0.37 \\
& Mean & 10.15 & 9.01 & 12.17 & 1.00 \\
\hline$a, b, c \ldots . .$.
\end{tabular}

$a, b, c . . . .$. Means in the same row with different superscript are significantly different $(P<0.05)$.

No significant differences were observed in the mean values of TVFA's among treatments. In the same trend, Khattab et al. (2012) and Chanjula et al. (2014) recorded the same result on lactating goats.

The mean values of rumen $\mathrm{NH}_{3}-\mathrm{N}$ concentrations did not significantly differ among treatments. In contrast, mean values of ruminal $\mathrm{NH}_{3}-\mathrm{N}$ concentrations were increased either with glycerol alone or with fibrolytic enzymes compared with control (Khattab et al., 2012). Regarding all sampling times, $\mathrm{NH}_{3}-\mathrm{N}$ concentrations were the highest for R3 compared to R2 and R1. The increase in rumen $\mathrm{NH}_{3}-\mathrm{N}$ concentration with the fibrolytic enzymes treatment may be due to higher $\mathrm{CP}$ content and digestibility which mean higher fermentation rate with fibrolytic enzymes addition.

\section{Blood plasma parameters:}

Data in Table (5) showed that inclusion of glycerol with or without fibrolytic enzyme in lactating goats rations had no significant $(\mathrm{P}<0.05)$ effect on all blood plasma parameters. Also, Khattab et al. (2012) found the same result. Boyd et al. (2013) showed that using glycerol in dairy cows rations had no significant effect on blood urea concentrations, which means a good balance between rationary energy and rumen degradable protein among treatments (Wilbert et al., 2013).

All measured blood plasma parameters of the experimental animals are within the normal physiological range reported by Merck (2014). So, these data showed that adding crude glycerol have no negative effect on animals' health. 
Egyptian J. Nutrition and Feeds (2015)

Table (5). Effect of experimental rations on blood plasma parameters of lactating goats.

\begin{tabular}{lcccc}
\hline \multirow{2}{*}{ Parameters } & \multicolumn{3}{c}{ Experimental rations } & \multirow{2}{*}{ \pm SE } \\
\cline { 2 - 4 } & $\mathrm{R} 1$ & $\mathrm{R} 2$ & $\mathrm{R} 3$ & 0.001 \\
Total protein $(\mathrm{g} / \mathrm{dl})$ & 6.10 & 6.20 & 6.20 & 0.001 \\
Albumin $(\mathrm{g} / \mathrm{dl})$ & 2.95 & 2.90 & 2.97 & 0.49 \\
AST $(\mathrm{u} / \mathrm{L})$ & 72.25 & 74.00 & 72.75 & 1.14 \\
ALT $(\mathrm{u} / \mathrm{L})$ & 19.00 & 15.00 & 19.00 & 1.21 \\
Urea-N (mg/dl) & 27.00 & 29.25 & 29.00 & 0.001 \\
Creatinine (mg/dl) & 0.65 & 0.90 & 0.95 & \\
\hline
\end{tabular}

\section{Milk yield and composition:}

Data dealing with dry matter intake (DMI), milk yield and composition and efficiency are presented in Table (6). Although, there was no significant $(\mathrm{P}<0.05)$ difference in DMI among treatments, goats fed control (R1) had the highest DMI value. In the same trend, Zymon et al. (2012), wilbert et al. (2013) and Chanjula et al. (2014) found that feeding glycerol did not affect on DMI. While, a decrease in DMI with glycerol inclusion in rations was recorded by Boyd et al. (2013).

No significant differences were observed either in actual milk yield or $4 \%$ fat corrected milk (FCM) among treatment, but control group recorded the best values. The decrease in milk production with glycerol inclusion (R2 and R3) may be due to the decrease in DMI and digestibility. Khattab et al. (2012) found that goats fed glycerol alone had lower milk and FCM yields while, adding fibrolytic enzyme to glycerol ration improved milk production. However, Kass et al. (2012) and Wilbert et al. (2013) did not find any significant differences in milk yield when dairy cows fed glycerol.

Table (6). Effect of experimental rations on dry matter intake, milk yield and composition and efficiency of lactating goats.

\begin{tabular}{|c|c|c|c|c|}
\hline \multirow{2}{*}{ Item } & \multicolumn{3}{|c|}{ Experimental rations } & \multirow{2}{*}{$\pm \mathrm{SE}$} \\
\hline & $\mathrm{R} 1$ & $\mathrm{R} 2$ & R3 & \\
\hline DMI, g & 1053 & 922 & 931 & 33.59 \\
\hline Milk Yield (g/h/d) & 1173 & 977 & 965 & 85.60 \\
\hline $4 \%$ FCM $(\mathrm{g} / \mathrm{h} / \mathrm{d})$ & 1032 & 754 & 837 & 82.76 \\
\hline \multicolumn{5}{|l|}{ Milk composition, $\%$} \\
\hline Fat & $3.18^{\mathrm{a}}$ & $2.46^{\mathrm{b}}$ & $3.08^{\mathrm{ab}}$ & 0.15 \\
\hline Protein & 3.45 & 3.52 & 3.31 & 0.01 \\
\hline Lactose & 3.40 & 3.51 & 3.27 & 0.01 \\
\hline $\mathrm{TS}$ & 10.58 & 10.05 & 10.17 & 0.23 \\
\hline SNF & 7.40 & 7.59 & 7.09 & 0.14 \\
\hline Ash & 0.55 & 0.56 & 0.51 & 0.001 \\
\hline \multicolumn{5}{|c|}{ Milk constituents yield, $\mathrm{g} / \mathrm{h} / \mathrm{d}$} \\
\hline Fat & 37.30 & 24.03 & 29.72 & 3.36 \\
\hline Protein & 40.47 & 34.39 & 31.94 & 3.22 \\
\hline Lactose & 39.88 & 34.29 & 31.56 & 3.17 \\
\hline $\mathrm{TS}$ & 124.10 & 98.19 & 98.14 & 10.04 \\
\hline SNF & 86.80 & 74.15 & 68.42 & 6.89 \\
\hline Ash & 6.45 & 5.47 & 4.92 & 0.54 \\
\hline \multicolumn{5}{|l|}{ Efficiency } \\
\hline Milk yield/DMI, g/g & 1.11 & 1.06 & 1.04 & 0.01 \\
\hline
\end{tabular}

Contents and yields of protein, lactose, TS, SNF and ash and fat yield were not affected by treatment, with the exception of the milk fat content which was significantly $(\mathrm{P}<0.05)$ decreased with glycerol inclusion to the ration (R2). It was showed that the main components generated from complete fermentation of glycerol are propionate and particularly butyrate. Therefore, lower milk fat contents could 
be expected as glycerol inclusion in lactating animals' rations (Boyd et al., 2013 and Carvalho et al., 2011).

Addition of fibrolytic enzyme (ALLZYME ${ }^{\mathrm{TM}}$ ) to glycerol ration (R3) showed to alleviate the negative effect of glycerol on milk fat content compared with control (R1). This result could be explained by the positive effect of fibrolytic enzyme on ruminal $\mathrm{pH}$ stabilization and digestion improvement (Arriola et al., 2011 and Kung et al., 2000). This result agreed with Khattab et al. (2012).

It was observed that milk efficiency as milk yield, g/DMI,g did not significantly $(\mathrm{P}<0.05)$ differ among treatments. The insignificant differences either in milk yield or DMI among different groups could be the reason. Also, no significant effect in milk efficiency with feeding glycerol was observed by Zymon et al. (2012) and Boyd et al. (2013).

\section{CONCLUSION}

Results indicated that substitution of yellow corn by crude glycerol at $50 \%$ might be required the addition of fibrolytic enzymes to alleviate the negative effects of glycerol in ration on digestion and productive performance of lactating Baladi goats.

\section{REFERENCES}

Abo El-Nor, S.; A.A. AbuGhazaleh; R.B. Potu; D. Hastings and M.S.A. Khattab (2010). Effects of different levels of glycerol on rumen fermentation and bacteria. Anim. Feed Sci. Technol., 162: 99105.

Abu Ghazaleh, A.A.; S. Abo El-Nor and S.A. Ibrahim (2011). The effect of replacing corn with glycerol on ruminal bacteria in continuous culture fermenters. J. Anim. Physiol. Anim. Nutr., 95: 313-319.

AOAC (1995). Official Methods of Analysis of AOAC International, 16th Ed. Vol.1, "Agricultural, Chemicals, Contaminants, Drugs". Washington, D.C., USA, 521p.

AOAC (2012). Official Methods of Analysis of AOAC International, 19th Ed. Vol.1, "Animal feed". Maryland, USA, chapter 4:1-77.

Arriola, K.G.; S.C. Kim; C.R. Staples and A.T. Adesogan (2011). Effect of fibrolytic enzyme application to low- and high-concentrate diets on the performance of lactating dairy cattle. J. Dairy Sci., 94: 832841.

Azzaz, H.H. (2009). Effect of cellulytic enzymes addition to diets on the productive performance of lactating goats. M.Sc. Thesis, Fac. Agric., Cairo Univ., Egypt, 141 p.

Boyd, J.; J.K. Bernard and J.W. West (2013). Effects of feeding different amounts of supplemental glycerol on ruminal environment and digestibility of lactating dairy cows. J. Dairy Sci., 96: 470-476.

Boyd, J.; J.W. West and J.K. Bernard (2011). Effects of the addition of direct-fed microbials and glycerol to the diet of lactating dairy cows on milk yield and apparent efficiency of yield. J. Dairy Sci., 94, 4616-4622.

Carvalho, E.R.; N.S.Schmelz-Roberts; H.M. White; P.H. Doane and S.S. Donkin (2011). Replacing corn with glycerol in diets for transition dairy cows. J. Dairy Sci., 94: 908-916.

Chanjula, P.; P. Pakdeechanuan and S.Wattanasit (2014). Effects of diet crude glycerin supplementation on nutrient digestibility, ruminal fermentation, blood metabolites and nitrogen balance of goats. Asian Australas. J. Anim. Sci., 27:365-374.

Colombatto, D.; F.L. Mould; M.K. Bhat; D.P. Morgavi; K.A. Beauchemin and E. Owen (2003). Influence of fibrolytic enzymes on the hydrolysis and fermentation of pure cellulose and xylan by mixed ruminal microorganisms in vitro. J. Anim. Sci., 81:1040-1050.

Donkin, S.S.; S.L. Koser; H.M. White; P.H. Doane and M.J. Cecava (2009). Feeding value of glycerol as a replacement for corn grain in rations fed to lactating dairy cows. J. Dairy Sci., 92: 5111-5119. 
Doumas, B.; W. Wabson and H. Biggs (1971). Albumin standards and measurements of serum with bromochresol green.Clin. Chem. Acto., 31:87.

Duncan, D.B. (1955). Multiple range and multiple F tests. Biometrics, 11: 1-42.

Farahat, E.S.A. (2014). Using biologically treated date kernels in lactating rations. Ph.D. Thesis, Fac. Agric., Cairo Univ., Egypt, 126p.

FDA. (2006). Code of Federal Regulations, 21 CFR 582.1320, Title 21, Vol. 6, 21CFR582.1320. http://edocket.access.gpo.gov/cfr_2002/aprqtr/21cfr582.1320.htm

Forbes, R.M. and W.P. Garrigus (1948). Application of a lignin ratio technique to the determination of the nutrient intake of grazing animals. J. Anim. Sci., 7: 373-382.

Gallups, W.D.; C.S. Hobbs and H.M. Briggs (1945). The use of silica as a reference substance in digestion trials with ruminants. J. Anim. Sci., 4: 68-71.

Goering, H.K. and P.J. Van Soest (1970). Forage fiber analysis (Apparatus, Reagents, Procedures and Some Applications) USDA. Agricultural handbook, Washington, DC, USA, 379p.

Goff, J.P. and R.L. Horst (2001). Oral glycerol as an aid in the treatment of ketosis/fatty liver complex. J. Dairy Sci., 84(Suppl.1): 153. (Abstr.)

Hanafy, M.A.; M.S.H. Youssef; A.M. Badr; W.M.A. Ghoneem and M.R. Rashid (2015). In-vitro evaluation of diet containing crude glycerol as a substitute for corn with some additives. Egyptian J. Nutrition and Feeds, 18:163-171.

Kass, M.; T. Ariko; T. Kaart; E. Rihma; M. Ots; D. Arney and K. Olav (2012). Effect of replacement of barley meal with crude glycerol on lactation performance of primiparous dairy cows fed a grass silage-based diet. Livest. Sci., 150: 240-247.

Kerr, B.J.; T.E. Weber; W.A. Dozier and M.T. Kidd (2009). Digestible and metabolizable energy content of crude glycerin originating from different sources in nursery pigs. J. Anim. Sci., 87: 4042-4049.

Khattab, M.S.; S.A.H. Abo El-Nor; H.M.A. El-Sayed; N.E. El-Bordeny; M.M. Abdou and O.H. Matloup (2012). The effect of replacing corn with glycerol and fibrinolytic enzymes on the productive performance of lactating goats. International J. Dairy Sci., 7: 95-102.

Kośmider, A.; K. Leja and K. Czaczyk (2011). Improved Utilization of Crude Glycerol By- Product from Biodiesel Production, Biodiesel- Quality, Emissions and By-Products, Dr. Gisela Montero (Ed.), ISBN: 978-953-307-784-0.http://www.intechopen.com/books/biodiesel-qualityemissions- and-byproducts/improved-utilization-of-crude-glycerol-by-product-from-biodiesel-production.

Kung, L.Jr.; R.J. Treacher; G.A. Nauman; A.M. Smagala; K.M. Endres and M.A. Cohen (2000). The effect of treating forages with fibrolytic enzymes on nutritive value and lactation performance of dairy cows. J. Dairy Sci., 83:115-122.

Mach, N.; A. Bach and M. Devant (2009). Effects of crude glycerin supplementation on performance and meat quality of Holstein bulls fed high-concentrate diets. J. Anim. Sci., 87: 632-638.

Merck (2014). The Merck Veterinary Manual. http://www.merckmanuals.com/vet/appendixes/reference_guides/serum_biochemical_reference_range s.html.

Mertens, D.R. (1978). Effect of buffers upon fiber digestion. In: Regulation of acid-base balance symposium", Arizona Inn, Tucson, Arizona, USA, pp.43-108.

Morgavi, D.P.; K.A. Beauchemin; V. Nsereko; L.M. Rode; A.D. Iwaasa; W.Z. Yang; T.A. McAllister and Y. Wang (2000). Synergy between ruminal fibrolytic enzymes and enzymes from Trichoderma longibrachiatum. J. Dairy Sci., 83: 1310-1321.

Newbold, J. (1997). Proposed mechanisms for enzymes as modifiers of ruminal fermentation. In: "Proceedings of the 8th Annual Florida Ruminant Nutrition Symposium", Gainesville, Florida, USA, pp.146-159.

NRC (1981). Nutrient requirements of goats: angora, dairy and meat goats in temperate and tropical countries. Washington, D.C. National Academy Press (eds.). 


\section{Ghoneem et al.}

Nsereko, V.L.; D.P. Morgavi; K.A. Beauchemin; L.M. Rode; A.F. Furtado and T.A. McAllister (2000). Effects of feeding fungal feed enzyme preparation on the rumen microbial population. Reprod. Nutr. Dev., 40: 219-225.

Patton, F.G. and S.R. Grouch (1977). Colorimetric determination of urea, Anal. Chem., 49: 468.

SAS (2009). Statistical Analysis System. User's Guide: Statistics. Version 9.2.SAS Inst. Inc., Cary, NC., USA. pp. 7869.

Schröder, A. and K.H. Südekum (1999). Glycerol as a by-product of biodiesel production in diet for ruminants. Paper no. 241 in New Horizons for an Old Crop. Proc. 10 ${ }^{\text {th }}$ Int. Rapeseed Congr., Canberra, A.N. Wratten and P.A. Salisbury, (eds.) The Regional Institute Ltd., Gosford, New South Wales, Australia.

Snedecor, G.W. and W.G. Cochran (1982). Statistical Methods.7th ed. Iowa State Unvi. Press, Ames, Iowa, USA, 213p.

Steel, R.G.D. and J.H. Torrie (1980). Principles and procedures of statistical analysis.2nd ed. Mc GrowHill; London.

Thompson, J.C. and B. He (2006). Characterization of crude glycerol from biodiesel production from multiple feedstocks. Applied Engineering of Agriculture, 22: 261-265.

Tietz, N.W. (1986). Text Book of Clinical Chemistry. W. B. Saunders (eds.), Philadelphia, pp. 1271.

Tietz, N.W. (1990). Clinical Guide to Laboratory Tests 2nd Ed. Philadelphia.

Wang, Y.; X. Wang; Y. Liu; S. Ou; Y. Tan and S. Tang (2009). Refining of biodiesel by ceramic membrane separation. Fuel Process. Technol., 90: 422-427.

Warner, A.C.J. (1964). Production of volatile fatty acids in the rumen. Methods of measurements. Nutr. Abst. Rev., 34:339.

Wilbert, C. A.; Ê.R. Prates; J.O.J. Barcellosc and J. Schafhäuser (2013). Crude glycerin as an alternative energy feedstuff for dairy cows. Anim. Feed Sci. Technol., 183: 116-123.

Yang, W.Z.; K.A. Beauchemin and L.M. Rode (1999). Effects of an enzyme feed additive on extent of digestion and milk production of lactating dairy cows. J. Dairy Sci., 82:391-403.

Young, D.S. (1990). Effects of drugs on clinical laboratory tests, 3rd Ed. Washington, D.C., AACC Press, pp. 232.

Zymon, M.; J. Strzetelski; I. Furgał-Dierżuk; J. Kowalczyk and S. Osięgłowski (2012). The effectiveness of rapeseed cake and glycerine in feeding dairy cows. J. Anim. and Feed Sci., 21:49-64. 
تأثير الجليسرول الخام كإحلال من الأذرة مع أو بدون الانزيمات المحلة للألياف على الآداء الإنتاجى للماعز البلاى الحلاب البيرول

\author{
وفاء مصطفى على غنيم، مرفت سيد حسن يوسف2ّ محمد رشيد سلامة.2 2

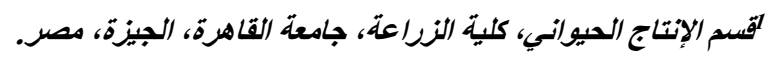

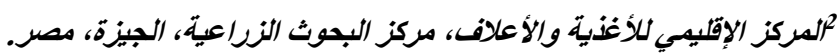

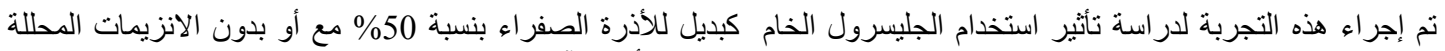

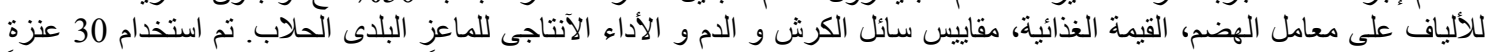

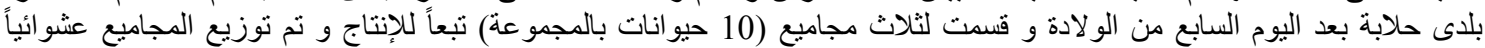

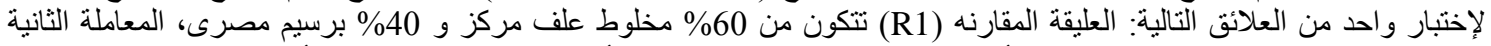

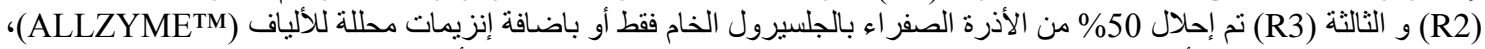

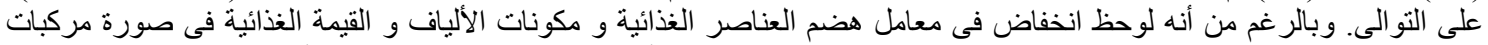

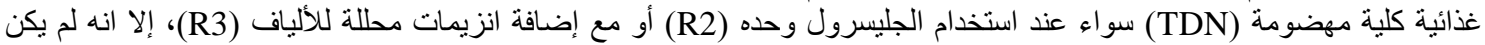

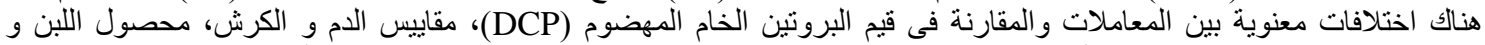

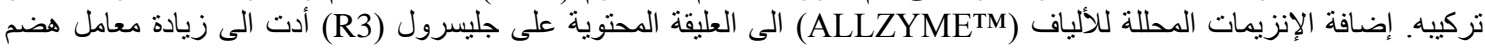

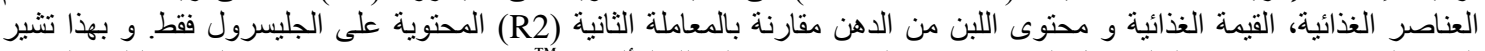

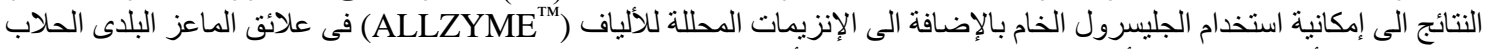

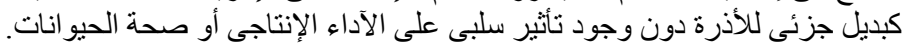

